\title{
PESAN BEDHAYA BANYU NING KALI BAGI AKUNTANSI MANAJEMEN AIR: PENDEKATAN EKOFENOMENOLOGI
}

\author{
Whedy Prasetyo \\ e-mail:whedy.p@gmail.com \\ Fakultas Ekonomi dan Bisnis Universitas Jember
}

\begin{abstract}
The local wisdom of bedhaya banyu ning kali dance to express management accounting of water as the aim of this study, with the qualitative approach of ecophenomenology used. The results of this study make the added value of local wisdom in identifying, recognizing, quantifying, reporting, and guaranteeing information on water, rights and claims, and obligations to water in water accounting. The activity manifests thanks to the perfection of human life for the generosity of the soul over the gift of water as source life. Bedhaya banyu ning kali dances this time provide evidence that the continuity of springs is not a factor in the size and location of water, but it is necessary to include how humans preserve it, as a manifestation of life activities not only today, but forever or hereditary. Embodiments that provide additional information in the GRI 300 sustainability report on Environmental Impacts, especially GRI 303-3 for the sustainability of water use.
\end{abstract}

Key words: dance of bedhaya banyu ning kali; management accounting of water; ecofenomenology; and water accounting.

\begin{abstract}
ABSTRAK
Kearifan lokal tarian bedhaya banyu ning kali untuk mengungkapkan akuntansi manajemen air sebagai tujuan penelitian ini, dengan pendekatan kualitatif ekofenomenologi yang digunakan. Hasil penelitian menjadikan nilai tambah kearifan lokal ini dalam mengidentifikasi, mengakui, mengkuantifikasi, melaporkan, dan menjamin informasi atas air, hak dan klaim, serta kewajiban terhadap air di dalam akuntansi air. Aktivitas wujud syukur kesempurnaan hidup manusia untuk kemurahaan jiwa atas anugerah air sebagai sumber kehidupan. Tarian bedhaya banyu ning kali ini memberikan bukti bahwa kelestarian sumber mata air (sendang) bukan faktor ukuran sumber dan lokasi air saja, namun perlu untuk dimasukkan bagaimana manusia menjaga kelestariannya, sebagai perwujudan aktivitas hidup bukan hanya sesaat hari ini, tetapi untuk selamanya atau turun temurun. Perwujudan yang memberikan tambahan dalam sustainability report (laporan keberlanjutan) GRI 300 tentang Environmental Impacts khususnya GRI 303-3 atas keberlanjutan penggunaan air.
\end{abstract}

Kata kunci: tarian bedhaya banyu ning kali; akuntansi manajemen air: ekofenomenologi; dan akuntansi air.

\section{PENDAHULUAN}

Hujan abu dari letusan Merapi yang mengguyur daerah sekitar tak menyurutkan para perupa dan masyarakat Wonorejo untuk selalu bersyukur atas limpahan berkah dari Yang Maha Kuasa. Berkah ini terus mengalir sederas mata air Sendang Bagong (Ki Sentot Subagyo (pemilik sanggar tari Bedhaya Banyu Ning Kali), wawancara 06 Oktober 2018 di Bantul Yogyakarta). Bedhaya banyu ning kali merupakan tari sebagai wujud syukur atas limpahan air yang mengaliri sendang bagong. Tari ini merupakan wujud syukur tersedianya cukup air bagi kebutuhan sehari-hari. Wujud syukur yang menghilangkan sifat serakah untuk mengeksploitasi sumber mata air. Hilangnya sifat serakah memberikan kesadaran menjaga tersedianya air sebagai sumber kehidupan. Kesadaran untuk merawat dengan tidak melakukan penamba- 
ngan serampangan dan pencemaran di sepanjang bantaran kali. Kondisi menjaga sumber mata air tersebut menurut Sindhunata (2015:33) merupakan kesadaran rasa dalam mengerti pentingnya ketersediaan air dalam hidup. Hidup bagi Sindhunata lebih lanjut dijelaskan sebagai bentuk terjalinnya hubungan harmonis antara tubuh dan air. Ketika hubungan tersebut terpecah maka hilangnya hidup pasti terjalin. Penjelasan yang sejalan dengan Mulder (2011:78) yang menyatakan bahwa:

"Kehidupan di Jawa, kehidupan dalam masyarakat dan air, sudah dipetakan dan tertulis dalam macammacam prastasti dalam bentuk simbol Bunga Teratai yang mengatur kaidahkaidah etika hidup manusia dengan air. Simbol ini merupakan keselarasan dalam masyarakat untuk menekankan hubungan syukur dengan Tuhan melalui sikap nrimo, sabar, waspada, eling adap asor (rendah hati) lan prasaja (sahaja)."

Air dalam hidup manusia Jawa memberikan perhatian terjaminnya hidup dunia. Mengapa demikian? Karena air merupakan nilai "Keadilan Sejati", yaitu rasa yang memiliki kepribadian, tingkah laku, dan hidup yang "adil" seimbang, dan selaras", oleh karena ia memiliki sifat-sifat kesempurnaan dan ajaran-ajaran kebenaran yang adil, seimbang, dan selaras (Endraswara, 2010:100101). Air lebih lanjut sebagai tolok ukur usaha manusia untuk hidup nilai "Keadilan Sejati" menentukan bahwa usaha hidup yang luhur adalah yang dilandasi dan dituntun oleh nilai "Keadilan Sejati" yang ditujukan terjaga dan terpelihara sumber mata air untuk hidup (Endraswara, 2010:101; Sabdacarakatama, 2011:56; Ahmad, 2014:43).

Kesadaran untuk menjaga dan melestarikan sumber mata air bermakna tergantungnya hidup manusia untuk membutuhkan air, artinya tanpa air yang bersih, manusia tidak bisa bertahan hidup. Kondisi ini menunjukkan manusia tidak bisa hidup dengan baik apabila mengonsumsi air tercemar, air kotor, atau yang terkontaminasi zat kimia berbahaya. Kalaupun bisa hidup, tidak akan dapat bertahan lama. Lebih lanjut, manusia yang mengkonsumsi air tercemar, usianya tidak panjang karena berbagai macam penyakit yang berasal dari air tercemar. Air yang bersih dan bebas dari pencemaran menjadi kebutuhan "mutlak" manusia dalam melangsungkan kehidupannya (Sindhunata, 2015:37; Widyawati, 2012:33).

Dalam arti fisik penjelasan di atas, merujuk pada penyataan Handoko (2014) dan Pambagio (2015) bahwa kelestarian air memberikan manfaat besar bagi manusia dibandingkan apabila tercemar menimbulkan penyakit dan lama kelamaan cadangan air bersih akan habis. Situasi ini membuat biaya hidup bertambah dengan tambahan dana untuk membeli air karena langkanya air bersih.

Kelangkaan air merupakan salah satu aspek yang menyebabkan stres air (water stress). Stres air mengacu pada ketidak mampuan dalam pemenuhan permintaan manusia dan ekologi akan air. Selain kelangkaan air, aspek lain penyebab stres air adalah kualitas air, arus lingkungan, dan aksesibilitas air (Schulte, 2014). Stres air terlihat dari munculnya bencana pencemaran, kekeringan, dan sulitnya sumber mata air bersih. Kondisi yang diakibatkan pengelolaan krisis ekosistem air dalam memberikan kesadaran kelestarian keberadaan sumber mata air. Investasi pemanfaat air sebagai komoditas cenderung mengorbankan daya dukung lingkungan di satu sisi dan di sisi lain jadi keserakahan aktivitas manusia sendiri.

Kalau manusia mau sadar, mestinya sebagaimana dinyatakan Sindhunata (2015: 42) bahwa air menjadi mutlak dalam menjaga kualitas hidup, sehingga menghindari segala bentuk aktivitas yang mencemari lingkungan, termasuk lingkungan air. Kalau air yang bersih sudah tercemar dan terkontaminasi zat-zat berbahaya, tentu air itu tidak layak untuk diminum ataupun keperluan-keperluan lainnya. Di samping faktor ini menurut Lako 
(2018:21,78) membuat biaya lingkungan untuk memulihkan kembali keberadaan sumber air yang bersih membutuhkan waktu lama dengan jumlah yang besar.

Situasi seperti itu membuat siapa yang paling rugi kalau air tercemar dan kering? Tentu saja, manusia! Ya, manusialah yang paling rugi. Karena tindakan egoislah yang mengakibatkan hilangnya sumber air bersih. Air yang seharusnya dijaga kebersihan agar tetap sehat berubah menjadi air tercemar, keruh dan menimbulkan berbagai penyakit berbahaya akibat perbuatan manusia sendiri. Jadi sebagaimana Achmad (2014:15; 2018:28) menjelaskan peran budaya tingkah laku manusia yang bertanggung jawab menjadi syarat utama keberlangsungan sumber mata air. Budaya ini menunjukkan manajemen atas sumber daya air bagi aktivitas informasi pertanggungjawaban penggunaan, pemanfaatan dan pemeliharaan ketersediaan air (Nasir et al. 2014). Aktivitas informasi inilah yang menjadi dasar informasi akuntansi air.

Akuntansi air merupakan upaya pelaporan dalam bentuk transparansi dan pertanggungjawaban atas penggunaan air, serta menjadi salah satu cara dalam menjaga keberlanjutan lingkungan sekaligus keberlangsungan usaha jika sumber daya air yang digunakan dapat dijaga kelestariannya (Schulte, 2014). Pelaporan ini menunjukkan penilaian air secara ekonomi memiliki banyak manfaat, salah satunya adalah bahan acuan dalam mengatur kebijakan air (water policy) dan mendesain instrumen ekonomi dalam mencapai pengelolaan penggunaan sumber daya air yang lebih baik. Adapun instrumen ekonomi yang dimaksud terdiri atas hak milik (property rights) dan menjaga dari polusi air (Pambagio, 2015; Patrick, 2016). Di samping aspek ekonomi menurut Dahana (2015) bahwa air memberikan tuntutan bagi pengguna untuk mempertanggungjawabkan dan mengikutsertakan perlakuan dalam pemanfaatannya secara non ekonomi, misalnya aktivitas budaya menjaga keberlangsungan sumber daya air tersebut. Kedua faktor tersebut memberikan keselarasan dalam mengatur kebijakan air berdasarkan tatanan sosial masyarakat (Achmad, 2014:21; 2018:70). Tatanan ini memberikan pedoman dalam menjaga kelestarian air sebagai pengungkapan pertanggungjawaban. Pengungkapan yang didasarkan pada kesadaran kebutuhan air tidak bukan hanya untuk sesaat namun selamanya. Kesadaran ini merujuk pada Widyawati (2012:17) bahwa sumber air bukan diciptakan untuk kehidupan manusia sendiri, namun ada banyak kehidupan dan kekuatan yang telah menghidupinya atau yang memberi kehidupan atas sumber air, artinya apabila dirusak maka yang rugi adalah manusia dan seluruh kehidupan serta tidak bersyukur atas yang diciptakan-Nya.

Nilai kesadaran tersebut ditujukan untuk memelihara tatanan dan mencegah datangnya kerusakan (bala). Juga terlihat, bagaimanapun bahwa manusia memegang peran aktif dalam memelihara tatanan ini dan mampu mempengaruhi arahnya. Hubungan sosial yang tertata baik menjadi sebuah sarana menuju dan sebuah kondisi untuk meningkatkan-keadaan lestari sumber mata air (Mulder, 2011:136). Dalam hal ini, tentu saja manusia dituntut tidak rakus (serakah), tidak boros (berlebihan), dan tidak mudah mencemari (eksploitasi) sumber mata air ciptaan Tuhan Yang Maha Esa yang sejatinya harus dipelihara sepanjang hidup manusia, artinya air rusak maka kehidupan manusia rusak pula (Smith, 2010; Handoko, 2014; Schulte, 2014).

Paradigma manusia seperti itu memberikan sikap dan perilaku arif serta bijaksana dalam memaknai sekaligus memperlakukan air. Mengapa demikian? Karena manusia harus mengembangkan konsepsi tentang sumber mata air yang mengagungkan dan menghormati, juga menganggap sebagai sesuatu yang harus dilestarikan. Dengan demikian, melahirkan sikap apresiatif dan peduli terhadap keberadaan air di mana manusia hidup (Darwin, 2018). Dengan begitu, lebih lanjut Darwin (2018) 
menjelaskan bahwa manusia menyadari keberadaan air sama posisinya dengan manusia yang juga membutuhkan perhatian dan pemeliharaan, sebagai pengejawantahan kepedulian terhadap sumber mata air yang harus diperlakukan secara baik dan berkesinambungan. Hal ini sangat berkorelasi positif dengan perilaku kearifan yang dipercayai oleh masyarakat tertentu (Widyawati, 2012:21). Lebih lanjut Widyawati (2012:24), Endraswara (2010:33) dan Sabdacarakatama (2011:61-62) menjelaskan bahwa perilaku dengan menjadikan air sedulur sinarawedi (kalimat ini sepadan dalam bahasa Indonesia yaitu saudara kandung) diwujudkan melalui perlambang aktivitas tontonan dan tuntunan budaya tarian. Budaya ini sarat nilai-nilai luhur yang dinyakini dan dijaga secara turun-temurun sebagai desa mawa cara negara mawa tata (Kalimat ini sepadan dalam bahasa Indonesia yaitu desa mempunyai aturan sendiri, negara mempunyai tatanan sendiri.)

Kearifan lokal tarian bedhaya banyu ning kali yang bersifat locus memberikan kesadaran masyarakat tertentu. Kesadaran yang pada akhirnya berkembang sebagai sebuah nilai dalam internal masyarakat tersebut. Dikatakan bersifat locus, karena pada umumnya kearifan yang sarat nilai ini diberlakukan bagi sebuah masyarakat yang dibatasi oleh wilayah tertentu, dan hanya dapat dipahami oleh anggota masyarakat tertentu pula (Mulder, 2011:133; Sabdacarakatama, 2011:62; Sindhunata. 2015:42). Kendati kearifan lokal itu banyak bermuatan nilai-nilai yang berkembang dalam suatu masyarakat dalam satu kawasan tertentu, tetapi dalam realitas tidak kalah perannya dalam membentuk karakter masyarakat yang ada didalamnya (Achmad, 2014: 23; 2018:70).

Karakter tersebut memberikan seni dalam mengklasifikasikan komponen-komponen pemeliharan sumber mata air ke dalam kategori-kategori penggunaan air yang mencerminkan konsekuensi dari campur tangan manusia dalam siklus hidrologi, yang merupakan komponen pertanggungjawaban pelaporan air dalam GRI 300 tentang Environmental Impacts atas GRI 303 Water, yaitu 303-1 (Water withdrawal by sources), 303-2 (Water sources significantly affected by withdrawal of water) serta 303-3 (Water recycled and reused). Pelaporan yang memfokuskan bagaimana penggunaan dan aktivitas intenal dalam menggunakan air (NCSR, 2018). Aktivitas yang menurut Darwin (2018) sebagai aktivitas internal manajemen dalam menyajikan laporan keberlanjutan air.

Pentingnya aktivitas internal inilah yang membuat penelitian ini mendekatkan pada kearifan lokal tarian bedhaya banyu ning kali untuk pengungkapan akuntansi manajemen air. Mengapa demikian? Karena untuk memahami lebih dekat nilai locus dalam menghasilkan perilaku pengungkapan kelestarian lingkungan sumber mata air, maka yang menjadi perumusan masalah dan tujuan penelitian ini bagaimana tarian bedhaya banyu ning kali dalam pengungkapan akuntansi manajemen air tersebut. Pengungkapan ini menjadikan nilai tambah kearifan lokal dalam mengidentifikasi, mengakui, mengkuantifikasi, melaporkan, dan menjamin informasi, hak dan klaim, serta kewajiban terhadap air (GRI 303; Water Accounting Standards Board, 2009).

\section{TINJAUAN TEORETIS}

Sustainability report air sangat didominasi oleh cara yang dilakukan manusia untuk melestarikan keberadaannya (Darwin, 2018).

Sustainability report (Laporan Berkelanjutan) air merujuk pada Global Reporting Initiative (GRI) 303 Water menjelaskan tentang pelaporan tentang penggunaan sumber mata air. Penggunaan yang diuraikan dalam GRI 303-1, 2 dan 3 atas aspek penggaruh lingkungan dalam menjaga dan melestarikan air. Pelaporan ini menunjukkan bahwa penggunaan air menjadi sumber daya penting untuk ditampilkan dengan baik dan sejelas mungkin, sehingga dapat digunakan sebagai bahan pertimbangan para pembuat 
kebijakan dalam pengambilan keputusan. Konsep tersebut menjadi sumber dalam berbagai analisis ekonomi dan sumber dalam mengkaji berbagai tindakan untuk menjaga ketersediaan air. Kondisi yang menurut Darwin (2018) dapat menjadi bentuk transparansi dan pertanggung jawaban atas penggunaan air, serta menjadi salah satu cara dalam menjaga keberlanjutan lingkungan sekaligus keberlangsungan jika sumber daya air yang digunakan dapat dijaga kelestariannya. Oleh karena itu tindakan manusia menjadi fokus laporan berkelanjutan untuk air. Tindakan manusia memang peran utama bagaimana perlakuan, pengelolaan dan pengungkapan penggunaan secara rinci atas air. Tindakan yang berorientasi pada keperluan pokok hidup (main life) manusia atas air, sehingga keberadaannya sangat ditentukan pada peran aktif manusia. Hal ini sebagaimana dinyatakan dalam GRI303-3 bahwa sumber air yang secara signifikan dipengaruhi oleh pengambilan air. Hal yang perlu dilaporkan berdasarkan indeks tersebut adalah jumlah total sumber air yang secara signifikanterkena dampak pengambilan air berdasar kan: (1) ukuran sumber air; (2) apakah sumber tersebut merupakan kawasan lindung (secara nasional atau internasional) atau tidak; (3) nilai keaneka- ragaman hayati (seperti keragaman spesies dan endemik, jumlah spesies yang dilindungi); dan (4) nilai atau pentingnya sumber air terhadap masyarakat lokal dan masyarakat adat.

Keempat faktor tersebut menunjukkan laporan pertanggungjawaban manusia dalam penggunaan air. Sifat dari laporan ini merupakan rincian atau pengungkapan kualitatif lebih lanjut atas informasi yang terkait bahan baku atau informasi khusus air. Jika nantinya laporan tersebut dapat disajikan dalam satuan moneter, maka akan lebih memperjelas alokasi biaya pemeliharaan yang digunakan oleh manusia dalam hal sumber daya air dan pelestariannya dalam hal efektivitas dan efisiensi operasionalnya (Pambagio, 2015; Darwin, 2018). Proses yang memberikan peran dalam aktivitas pelestarian dan penggunaan air. Proses ini sejalan dengan fase keempat pengembangan akuntansi manajemen sebagai creation of value through effective resources use sebagaimana pada Gambar 1.

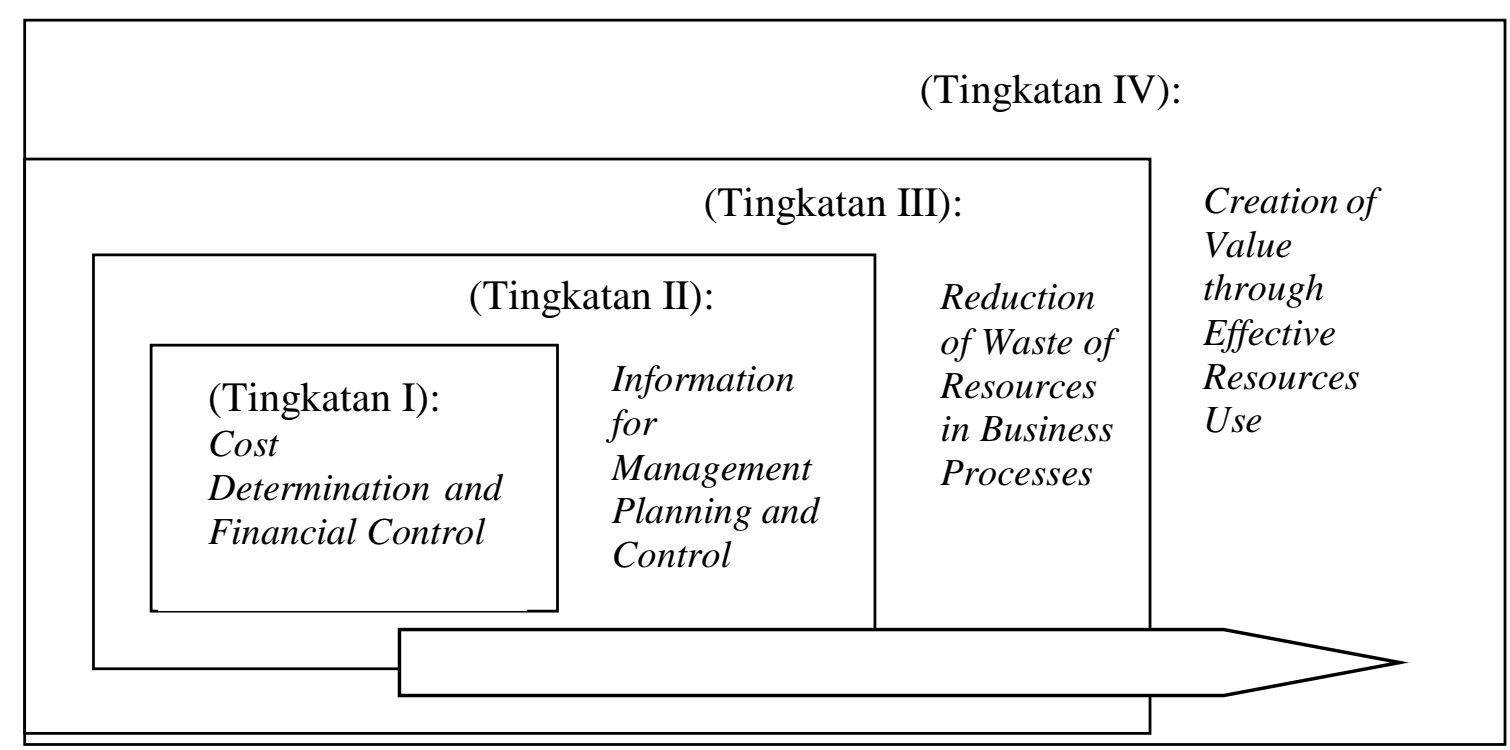

Gambar 1

Perkembangan Akuntansi Manajemen

Sumber: International Federation of Accountans (IFAC), Management Accounting Concepts (1998) 
Tindakan strategik tersebut menjadikan akuntansi manajemen menjadi bagian dari proses manajemen, seperti upaya kreatif dalam menjaga dan mengembangkan potensi lingkungan sebagai sumber daya bernilai tambah dengan keberlangsungannya terjamin. Fokus kreatifitas ini adalah bagian integral dari proses pengambilan keputusan (IFAC,1998:85,87). Dengan kreatifitas pemanfaatan membuat setiap tindakan berorientasi pada efektivitas penggunaan sumber daya. Hasilnya mendukung pembuatan keputusan strategis yang tepat. Ketepatan dalam konteks penggunaan internal sesuai dengan kemampuan yang dimiliki. Arya dan Mittendorf (2011), menyebutkan bahwa kemampuan internal memberikan inovasi tindakan manajemen dalam memanfaatkan sumber daya yang dimiliki. Kemampuan ini lebih lanjut dalam bentuk yang berbeda dapat mempengaruhi pengembangan perilaku dan aktivitas implementasi, serta dapat bersumber pada peningkatan kapabilitas yang dimiliki. Kapabilitas inilah sejalan dengan pemanfaatan sumber daya air yang bersumber pada kebutuhan internal. Lebih lanjut Schulte (2014), Pambagio (2015) dan Darwin (2018) menyatakan bahwa sumber air menjadi prioritas pengelolaan utama dalam tindakan aktivitas usaha. Air menjadi perhatian manajemen untuk menjamin keberlangsungan dan pencapaian keunggulan kompetitif.

Penjelasan di atas menuntut tindakan manajemen (internal) untuk pengungkapan lebih lanjut atas informasi bahan baku atau informasi khusus yang terkait dengan air. Jika nantinya laporan tersebut dapat disajikan dalam satuan moneter, maka akan lebih memperjelas alokasi biaya yang dipergunakan dalam pengelolaan dan pelestarian sumber daya air. Upaya untuk mencapai efektivitas dan efisiensi operasional perusahaan (GRI 303). Perwujudan aktivitas ini diperlukan informasi yang bermanfaat tentang persediaan dan penggunaan air. Informasi yang tertuang dalam upaya pelaku aktivitas (manajemen) meng- identifikasi, mengakui, mengkuantifikasi, melaporkan, dan menjamin informasi atas air,hak dan klaim, serta kewajiban terhadap air tersebut. proses inilah yang dimaksud dengan akuntansi air (water accounting) (Godfrey et. al., 2010; WASB, 2014).

Sifat dari laporan water accounting lebih lanjut menurut WASB (2014) merupakan rincian atau pengungkapan atas informasi tindakan dan alokasi biaya. Informasi yang digunakan untuk menjaga sekaligus melestarikan sumber daya air. Konsep ini membuat water accounting merupakan multidisiplin ilmu di mana penyusunannya tidak hanya berasal dari ranah akuntansi, melainkan juga memerlukan konvergensi dan harmonisasi dari instansi terkait air, pemerintah, pemerhati lingkungan, dan lainlain. Penjelasan yang sejalan dengan Molden (2007) bahwa water accounting adalah sebuah seni dalam mengklasifikasikan komponenkomponen saldo air ke dalam kategorikategori penggunaan air yang mencerminkan konsekuensi dari campur tangan manusia dalam siklus hidrologi. Kondisi tersebut menyebabkan timbulnya urgensi penerapan pengungkapan atau pelaporan atas air sebagai dukungan laporan keberlanjutan. Laporan pengungkapan air ini dapat dianalisis melalui dua aspek yang saling berkaitan, yakni lingkungan dan ekonomi. Penjelasan tersebut sebagaimana dinyatakan dalam ilustrasi gambar 2 .

Penjelasan yang menekankan pada peran aktif manusia dalam pertanggungjawaban penggunaan sumber daya air. Peran ini sangat dipengaruhi oleh budaya dan adat istiadat bahkan kepercayaan manusia itu sendiri (Endraswara, 2010:33; Sabdacarakatama, 2011:63; Widyawati, 2012:23; Achmad, 2018:29). Mengapa demikian? Sebagaimana lebih lanjut dijelaskan Achmad (2018:31) bahwa perilaku manusia dipengaruhi dari kehidupan masyarakat, sehingga peran aktif masyarakat mendorong keyakinan dan ketulusan dalam memperhatikan sumber daya air. Perhatian ini diwujudkan dalam tuntunan yang dipercaya dan dilestarikan secara turun-temurun melalui tontonan 
tarian bedhaya banyu ning kali. Tarian bedhaya banyu ning kali merupakan wujud nyata kesadaran perilaku manusia dalam menjaga kelestarian sumber mata air. Kesadaran ini diwujudkan dengan syukur tersedianya cukup air bagi kebutuhan sehari-hari.

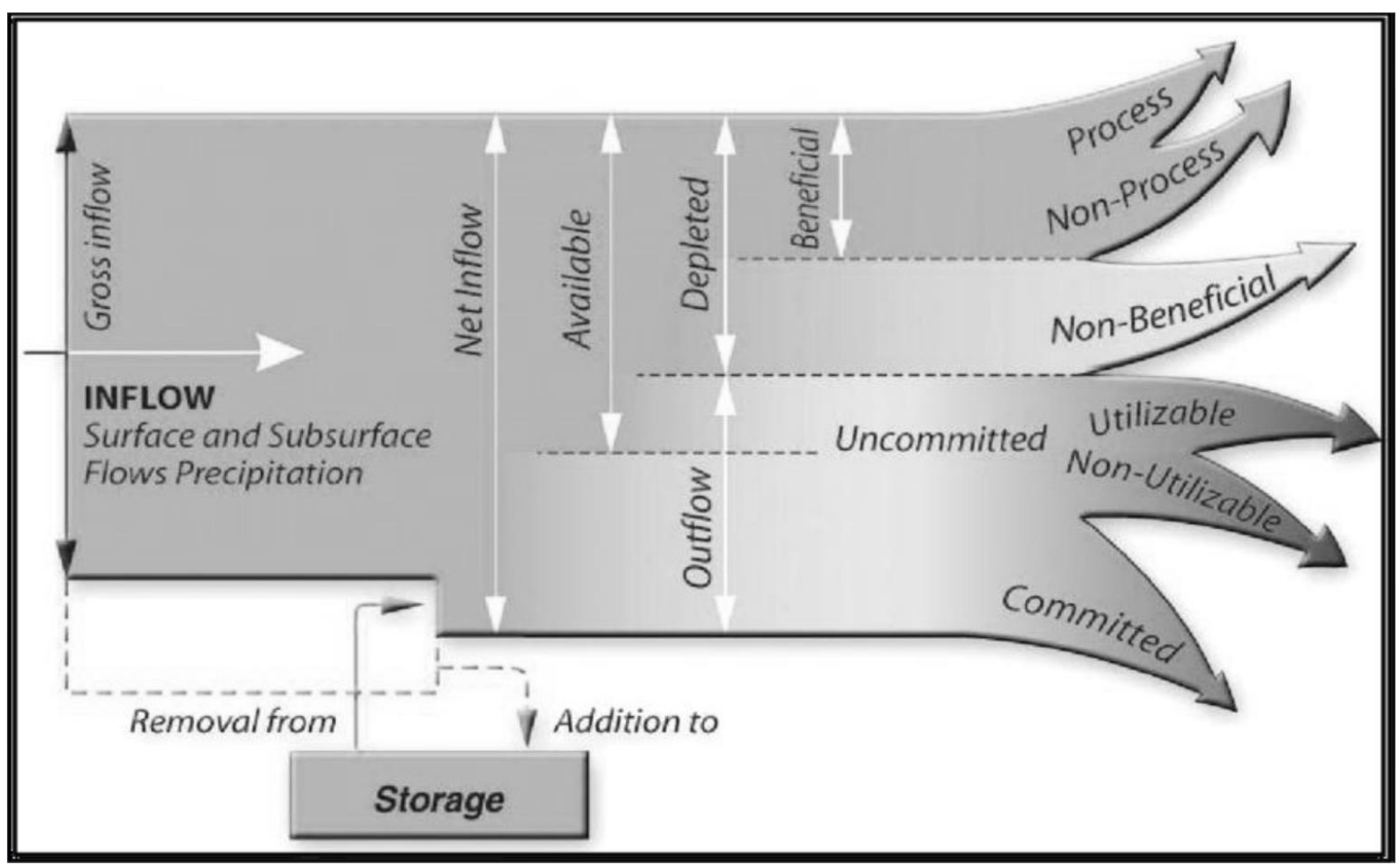

Gambar 2

Sumber: Molden, 2007

\section{Water Accounting}

Wujud syukur sebagaimana Achmad (2014:16; 2018:28) dan Endraswara (2010:34) menjelaskan dalam ritual mistis harmonis berupa tajamnya olah batin (raos), sehingga lebih tanggap terhadap isyarat batin (tanggap ing sasmita rasa). Isyarat batin seperti ini dinyakini merupakan firasat wahyu dyatmika ing gemah rimpah tirta bening langgenging urip.

(Kalimat ini sepadan dalam bahasa Indonesia yaitu Pemberian nyata untuk berlimpahnya air bersih bagi kelangsungan hidup.)

Gerakan tarian ini menunjukkan ketulusan net (batin) dan irama (tindakan) yang menghilangkan sifat serakah untuk mengeksploitasi sumber mata air (Achmad, 2014:15; Sindhunata, 2015:43). Hilangnya sifat serakah memberikan kesadaran menjaga tersediannya air sebagai sumber kehidupan. Keyakinan ini menurut Sindhunata (2015:43) dicapai dengan dukungan tradisi ritual budaya yang unik, yaitu tarian mengelilingi sumber mata air (sendang). Aktivitas yang diibaratkan wujud keheningan dan ketenangan batin.

Kenapa hal tersebut di atas dinyakini oleh masyarakat? Karena, sumber mata air yang jernih (banyu bening) menjadi simbol kekuatan batin yaitu jernihnya kehidupan. Dengan jernihnya kehidupan maka ketenteraman hidup terjamin. Ketenteraman ini bagi orang Jawa sebagai puncak harmonisasi hidup dengan lingkungan, artinya menghindarkan tindakan melakukan perusakan dan pencemaran di sumber dan sepanjang aliran mata air (Mulder, 2011:136; Widyawati, 2012:23). Tradisi tarian bedhaya banyu ning kali tersebut merupakan simbol. 
Simbol aktivitas kesadaran hidup manusia terhadap keberadaan sumber mata air. Simbol ini lebih lanjut menunjukkan aktivitas keharmonisan hidup. Harmonis sebagaimana Peneliti rasakan ketika menyaksikan tarian, dimana masyarakat mampu berkomunikasi lang- sung dengan realitas hidup lebih tinggi, artinya sikap dan pola pikir keberadaan sumber mata air (sendang) merupakan perwujudan aktivitas hidup bukan hanya sesaat untuk hari ini, tetapi untuk selamanya atau turun temurun.

\section{METODE PENELITIAN}

Bila pertanyaannya bagaimana sumber alam air yang ada (being) menjadi transparan, maka tradisi berpikir yang mengeras mesti diurai kembali, dan ketersembunyian yang telah terjadi dapat diluluhkan (Smith, 2010).

Maksudnya, anggapan umum perlu diurungkan untuk mencari tahu permasalahan subyek dari sumber mata air. Dalam hal ini, air dipandang sebagai suatu lingkungan atas fenomena yang ada. Pertama perlu ditegaskan pengertian metode ekofenomenologi, untuk memahami objek atau benda dengan nilai kebendaan itu sendiri. Hal ini bertujuan "merangkul" entitas sebagai petunjuk memahami air sebagai fenomena. Kedua, entitas itu dikurung untuk mencari pemahaman yang hakiki tentang fenomena alam. Heidegger dalam Dewi (2015:12) menekankan bahwa hal tersembunyi tentang subyek keberadaan lingkungan hanya dapat diketahui melalui metode fenomenologi, karena hanya melalui fenomenologi maka ontologi dimungkinkan.

Oleh karena itu untuk menguraikan penelitian ini, maka informan yang digunakan adalah: Pertama, Prof. Eko Ganis Sukoharsono, Ph.D, CSRA sebagai Chairman Board of Director Institute of Certified Sustainability Practitioners Indonesia, Kedua, Dr. Sarah Dewi sebagai pemerhati lingkungan hidup dan Kepala Studi Filsafat Universitas Indonesia, Ketiga, Prof. Dr. Andreas Lako sebagi penulis buku Akuntansi Hijau: Isu, Teori, dan Aplikasi, dan terakhir, Keempat, Ki Sentot Subagyo sebagai pemilik sanggar tari bedhaya banyu ning kali di Bantul Yogyakarta.

Keempat informan ini mampu memberikan penjelasan yang dapat diterima rasio maupun persepsi atas realitas air. Realitas yang tampak dapat dipecahkan secara ekofenomenologis, yaitu mencari substansi dari keberadaan lingkungan fenomena tersebut. Pengungkapan yang dilakukan mulai tanggal 06 Oktober 2018 sampai 22 Januari 2019.

\section{HASIL DAN PEMBAHASAN}

Air bukan suatu komoditas sehingga peran keramahan budaya menjaga kelestarian kebersihan dan kemurnian sangat diharapkan (Dahana, 2015:191).

Fenomena budaya tarian bedhaya banyu ning kali merupakan wujud kesadaran keberadaan air dalam mendukung keberlangsungan kehidupan. Kesadaran ini membuat air menjadi sumber kehidupan bagi manusia. Seperti yang diyakini Ki Sentot Subagyo bahwa:

Ku nyata ananing tirta mung awujud berkah sumadaya tari bedhaya banyu ning kali laku urip kanggone njaga lestarine banyu ngracik ing tumrap slametan [kenyataan tersedianya air merupakan bentuk keberadaan tari bedhaya banyu ning kali perjalanan aktivitas hidup menjaga kelestarian air sebagai wujud tasyakuran.

Ritual slametan dalam tari bedhaya banyu ning kali memperlihatkan hasrat mencari keselamatan dalam menjaga kelestarian air. Kegiatan ini ditujukan untuk memelihara tatanan dan mencegah datangnya kehancuran sumber mata air. Jadi, bagaimanapun bahwa manusia memegang peran aktif dalam memelihara tatanan ini dan mampu mempengaruhi keberadaan sumber air. Hubungan sosial yang tertata baik menjadi sebuah sarana menuju dan sebuah kondisi untuk meningkatkan keadaan terpeliharanya lingkungan sekitar (Mulder, 2011:136).

Pencapaian tersebut merupakan ekspresi perilaku dirinya sebagai kesadaran luhur dalam memperhatikan sumber mata 
air. Kesadaran luhur ini membuka kekuasaan Tuhan dalam menciptakan tersedianya air untuk hidup. Kondisi yang membuat hidup akan tenteram apabila pemberian Tuhan dijaga dan dipelihara kelestariannya. Rasa ini sebagaimana di ungkapan oleh Saras Dewi berikut ini:

Air merupakan simbol keberkahan oleh karenanya keberadaan menjadi sarat menjaga untuk lestari dengan wujud yang berupa tarian di sumber mata air. Ini bukan sembarang (biasa) namun ajaran moral dan tata kelakuan (atau code of conduct) yang diharapkan menjadi pedoman mengatur (atau memanage) air, sehingga dapat tercipta kondisi lingkungan yang lestari.

Pernyataan ini sejalan dengan Ki Sentot Subagyo bahwa:

Sendhang tari bedhaya banyu ning kali awujud berkah mangasah mingising budi memasuh malaning tirta kanggone urip tentrem simbol urip gumatung rasa syukur memayu hayuning bawono lumampahe grojokan tirta sak lawase [Seni tari bedhaya banyu ning kali wujud syukur mengasah kepekaan mata batin menghilangkan tindakan mencermari air untuk hidup tenteram simbol hidup tergantung rasa syukur menjaga kelestarian alam tersediannya air selamanya].

Kedua pernyataan tersebut menunjukkan kesadaran menjaga ketersediaan air. Kesadaran ini membawa sikap etis dan adil terhadap keberlangsungan air untuk kehidupan sebagai anugerah. Relasi yang menjadikan pengetahuan realitas dengan pemeliharaan menjadi satu kesatuan berpengaruh, sebagaimana dinyatakan Dewi (2018:61) bahwa relasi ketersediaan air dengan kebersihannya bergantung pada kesadaran sebagai anugerah Tuhan dengan kelestarian untuk menjaganya. Kelestarian menjadikan fokus bagaimana manusia untuk memeliharanya dalam pendekatan ekosistem. Pendekatan ini mengarahkan untuk mengakui betapa besar kehidupan manusia bergantung pada fungsi gabungan adanya air dan nutrisi untuk menjamin kelangsungan hidup manusia. Oleh karenanya manfaat pemeliharan dengan tindakan manusia menjadi kehidupan yang saling berhubungan. Penjelasan ini merujuk pada dialog di bawah ini:

Whedy : Jumlah dan kualitas air tidak terlepaskan oleh tindakan manusia secara langsung dikaitkan pada dampak ekologi dan biaya operasional

Andreas Lako : Benar...karena air merupakan salah satu aspek dalam kategori lingkungan. Aspek air tersebut diatur secara khusus dalam GRI Standards yaitu GRI 303, 307 dan 308. Pada 413 bahwa kemampuan masyarakat setempat dalam menjalankan fungsinya untuk menjaga kelestariannya. Perubahan tersebut memiliki dampak yang lebih luas pada kualitas hidup di daerah tersebut, termasuk konsekuensi ekonomi dan sosial. Oleh karena pelestariannya sangat tergantung pada tindakan manusianya sendiri.

Whedy : Kebenaran tindakan manusia merupakan langkah menjaganya ya...Prof?

Andreas Lako : Benar...tindakan yang berorientasi pada kelestariannya. Hal ini seperti budaya untuk menjaga kelestarian air. Caranya memang beda dengan disana namun inti dari konsep hasilnya sama bahkan lebih menjaga kelestariannya. Kalau ini jelas mendukung aplikasi 413 bahwa manusia memiliki potensi untuk mengurangi 


\author{
dampaknya pada lingku- \\ ngan sekitar. \\ Whedy : Budaya dalam tindakan \\ manusia bagaimana Prof?
}

Andreas Lako : Iya.........wujud bagaimana manusia memperlakukan air sebagai sumber kehidupan. Tindakan bisa berupa memelihara tumbuhan dan tidak meracuni, bahkan dengan selamatan atau bersih desa itu...lho... melalui tarian umumnya.

Whedy : Tarian bedhaya banyu ning kali bagaimana Prof?

Andreas Lako : Iya...iya...itu apa tadi?

Whedy : Bedhaya banyu ning kali... Prof

Andreas Lako : Bedhaya banyu ning kali... saya pernah mengingat dan membaca upaya tradisi budaya untuk memelihara kelestarian air. Tarian wujudnya namun konteks pelaksanaannya adalah untuk kelestarian lingkungan...bukan melihat cara nya namun komitmen untuk menjaganya. Komitmen menjaga itu sama dengan yang diharapkan pada GRI bahwa kelestarian air mempengaruhi kualitas pasokan air yang tersedia dalam hubungannya dengan masyarakat dan pengguna air lainnya... ini GRI. Jelas bagaimana masyarakat setempat mem berikan kontribusi untuk kelestarian air........atau bahasa orang Now disebut dengan charity. Dalam konteks di Jawa gerakan tarian bedhaya banyu ning kali ini pastilah seperti wujud peran dalam menjalankan pentingnya manusia dalam kelestarian ling- kungan...inilah charity-nya orang Jawa...Bangga... lho saya.

Gerakan tarian bedhaya banyu ning kali merujuk pada penjelasan Achmad (2018:178179) dan Widyawati (2012:73) sebagaimana wujud kesempurnaan hidup manusia untuk kemurahaan jiwa atas anugerah air sebagai sumber kehidupan. Tarian ini memfokuskan kesadaran akan pentingnya air untuk kehidupan. Hal ini sebagaimana juga dinyatakan oleh Ki Sentot Subagyo berikut ini:

Bedhaya banyu ning kali ngelambang simbol manungsa kang uperti laku pekertine marang banyu, yaiku batak, jangga utawwa gulu, dada, endhel ajeg, apit ngarep, apit mburi, endhel weton lan apit meneng [Tarian bedhaya banyu ning kali melambangkan budi pekerti manusia bagi air, yaitu jiwa dan pikiran, leher, dada, nafsu atau hasrat, lengan kanan, lengan kiri, kaki kanan dan kaki kiri].

Nilai adiluhung tarian bedhaya banyu ning kali tersebut membuat diri manusia menyadari sepenuhnya arti pentingnya pengelolaan keberlangsungan tersedianya air. Pertanggungjawaban terhadap air merupakan konteks utama dalam pengelolaan air (water manage) untuk lingkungan. Kegiatan pengelolaan yang merupakan wujud ruang lingkup pertanggungjawaban sosial untuk menjaga dan melestarikan keberadaan sumber air (Irewati dan Wahyuni, 2013; Agus, 2015; Patrick, 2016; Remali, et.al. 2016).

Pengelolaan air memberikan manfaat langsung pada kualitasnya. Kualitas ini memberikan keutamaan sebagaimana dinyatakan pedoman pelaporan keberlanjutan Global Reporting Initiative Standards (GRI Standards), System of Environmental-Economic Accounts for Water (SEEA-Water), hingga

Australian Water Accounting Standards (AWAS). Pedoman yang menyatakan bahwa perilaku masyarakat untuk menjaga dan memperhatikan lingkungan menunjukkan kelestarian dan terjaganya kualitas sumber 
air. Penjelasan ini sejalan dengan yang dinyatakan oleh Prof. Eko Ganis Sukoharsono, bahwa:

Pedoman peraturan GRI Standards 303 sebagai bagian dalam GRI 300 Environmental Impacts ataupun SEEAWater atau Undang-Undang dan lainnya merupakan petunjuk yang mengarahkan perilaku manusia bagaimana memperhatikan lingkungan. Untuk itu upaya ya...ada pada diri manusia bagaimana tindakan ataupun caranya. Kalau di sini akan lebih mengenai dengan didekatkan pada budaya...ya budaya tarian bedhaya banyu ning kali itulah yang menjadi cara untuk mendampingkan pedoman tersebut.

Pernyataan yang sama juga dinyatakan oleh Prof. Andreas Lako bahwa:

Memahami pedoman itu juga sejalan dengan budaya...kalau sudah mengena aplikasi kualitas air akan terjaga. Budaya yang saya maksud ya...peran dan upaya masyarakat melestarikan dengan tarian bedhaya banyu ning kali yang Anda maksud tadi itu lebih lestari.

Aplikasi dari tarian tersebut untuk merubah kesadaran masyarakat tentang pentingnya menjaga kelestarian sumber mata air. Hal ini sebagaimana dijelaskan Achmad (2014: 23; 2018:72) bahwa tarian bedhaya banyu ning kali ditangkap untuk mengajarkan tentang kesempurnaan hidup manusia. Kesempurnaan hidup dalam maksud yaitu menghargai kelestarian sumber mata air. Gerakan tarian menunjukkan bagaimana olah raga (perilaku) dan olah rasa (hati) menyatu untuk melestarikan sumber air. Hal ini sebagaimana juga pernyataan Ki Sentot Subagyo:

Unggah ungguhe tarian dudu mung hiburan ae, nanging tempate lan mubengi ing sendang karo nari nunjukake uripe banyu dadi maludara, lan anahata jaga lestarine banyu. Yo...tarian iki mung dilakoni ing sendang banyu ora ning pelataran
liyane.[Pendoman penampilan tarian bukan hanya hiburan saja, namun lokasi dan aktivitas mengelilingi sumber mata air dengan gerakan tarian menunjukkan mengalirnya air sebagai perhatian, dan kepercayaan untuk menjaga kelestarian air. Iya...tarian ini hanya ditampilkan di sumber mata air tidak ditempat lainnya.]

Pelambangan tarian bedhaya banyu ning kali tersebut menunjukkan bentuk komunikasi pertanggungjawaban seni tari untuk menjaga lestarinya sumber air sebagai wujud kepedulian sumber mata air. Pertanggung jawaban yang diwujudkan melalui media tontonan (hiburan) dan tuntunan (pedoman) yang sarat dengan tatanan (aturan) perilaku menjaga kelestarian air (Sindhunata, 2015:43; Achmad, 2018:176). Tatanan yang lebih lanjut dijelaskan oleh Achmad (2018:179) sebagai wujud syukur yang menghilangkan sifat serakah untuk mengeksploitasi sumber mata air. Hilangnya sifat serakah memberikan kesadaran menjaga tersediannya air sebagai sumber kehidupan Penjelasan ini sejalan dengan hasil penelitian yang dilakukan oleh Irewati dan Wahyuni, (2013), Nasir, et al. (2014), Remali, et.al (2016) dan Febiola (2018). Mereka menyatakan bahwa budaya perilaku manusia mendorong diterapkannya water accounting sebagai bagian dari tata kelola air yang baik. Sehingga menuntut agar kegiatan yang dilakukan harus berorientasi ramah lingkungan. Penerapan water accounting sangat ditentukan oleh kesadaran tanggung jawab perilaku manusia. Tanggung jawab yang difokuskan untuk menjaga dan melestarikan, sebagaimana dinyatakan Indeks pengungkapan yang digunakan adalah aspek air pada GRI Standards 303 dan informasi terkait air yang diminta oleh Carbon Disclosure Project (CDP) 2015.

\section{Bedhaya Banyu Ning Kali dalam Water Accounting}

Tatanan tarian bedhaya banyu ning kali pertanggungjawab manusia dalam memelihara sumber mata air (Sindhunata, 2015:46). 
Pengungkapan informasi pelaporan air sebagai dasar akuntansi air (water accounting) dipengaruhi oleh kesadaran pertanggungjawaban penggunaan air. Pengungkapan informasi secara naratif dan bahkan menggunakan data kuantitatif (GRI Standards 303). Proses ini mengindikasikan telah adanya kesadaran terkait pentingnya air dan pelaporan akan penggunaan air sebagai rekomendasi penerapan pelaporan air (Nasir, et al. 2014; Febiola, 2018).

Pelaporan water accounting mengungkapkan tentang pentingnya informasi dari pengungkapan informasi atas air tersebut. Manfaat informasi tersebut dapat memberikan indikasi pengguna air serta kelestariannya. Fokus kelestarian sebagaimana GRI Standards 303 menjadikan faktor utama dalam pelaporan ini. Kelestarian yang membutuhkan komitmen pengguna air dalam menjaga keberlangsungan ketersediaan dan kemurnian (kejernihan) kandungan air yang digunakan secara berkelanjutan.

Kelestarian air merupakan perhatian perilaku dalam penggunaan air itu sendiri untuk menjaga anugerah Tuhan (Mulder, 2011:23; Achmad, 2014:49). Perilaku yang sebagaimana Sindhunata (2015:43) dan Endraswara (2010:102) menegaskan pada tatanan-tatanan pelaksanaan budaya mikrokosmis (Tuhan) dan makrokosmis (antar makhluk hidup) sebagai wujud tuntunan menjaga sumber mata air yang harus dijalankan dan dilestarikan untuk membangun kehidupan rakyat yang tenteram. Tuntunan yang diwujudkan dalam media kesenian tari bedhaya banyu ning kali.

Tari bedhaya banyu ning kali terdiri dari jumlah 4 penari perempuan artinya simbol hubungan harmonis antara empat jati diri tersedianya air yaitu sumber, mancur, mili, dan seger. Keempat jati diri ini sebagaimana merujuk pada penjelasan Ki Sentot Subagyo:

Tandure tarian bedhaya banyu ning kali sing ngiteri sendang mung papat penari uga simbolake artine ukara mung kanggo bektine banyu kange lestarine urip manungso, yaiku sumber, mancur, mili lan seger. Ukura iki yen kudu digandeng supaya lestarine banyu kanggo urip. Sumber kanggonan arti yaiku asalne banyu, mancur artine mung muncrat ing tatanan kanggo panguripan, mili mung podho karo dalane banyu kanggo manfaate urip, lan terakhir seger awujud manfaate sing digunane [Penggunaan tarian Bedhaya Banyu Ning yang mengelilingi sumber mata air dilakukan oleh empat penari sebagai simbol menjaga kelestarian air untuk kelangsungan hidup manusia, yaitu sumber (asal), mancur (keluar), mili (mengalir), dan seger (segar). Ungkapan ini untuk mewujudkan lestarinya air sebagai penghidupan. Sumber artinya berasalnya air, mancur artinya keluar dari asalnya untuk hidup, mili sama dengan aliran air yang digunakan untuk hidup, dan terakhir seger sebagai perwujudan penggunaan air.]

Kesadaran terjaganya kelestarian air ini sejalan dengan yang dinyatakan dalam indeks GRI Standards 303 terkait air terdiri dari 303-1, 303-2, dan 303-3. Satu-satunya indeks yang tidak diproksikan terhadap elemen laporan water accounting adalah 3032 tentang sumber air yang secara signifikan dipengaruhi oleh pengambilan air. Hal yang perlu dilaporkan berdasarkan indeks tersebut adalah jumlah total sumber air yang secara signifikan terkena dampak pengambilan air berdasarkan: (1) ukuran sumber air; (2) apakah sumber tersebut merupakan kawasan lindung (secara nasional atau internasional) atau tidak; (3) nilai keanekaragaman hayati (seperti keragaman spesies dan endemik, jumlah spesies yang dilindungi); dan (4) nilai atau pentingnya sumber air terhadap masyarakat lokal dan masyarakat adat. Informasi 303-2 ini lebih bersifat kualitatif, maka tidak perlu disajikan dalam elemen laporan tetapi tetap diungkapkan secara jelas dalam catatan atas laporan water acconting (CALWA).

Interpretasi tersebut memberikan pendukung dalam melaksanakan GRI Standards 
303-2 sebagai tambahan didalam rancangan model untuk menambahkan kembali nomer 5 yaitu pemanfaatan pemeliharaan air dalam catatan pengungkapan atau Catatan Atas Laporan water accounting (CALWA). Mengapa perlu nomer 5? Karena tidak ada sumber muatan kualitatif untuk menjelaskan nomer 1 sampai 4 kalau tidak mengetahui bagaimana kelestarian terjaganya sumber air. Tarian bedhaya banyu ning kali memberikan bukti bahwa kelestarian sumber mata air bukan faktor ukuran sumber dan lokasi air saja namun yang perlu untuk dimasukkan bagaimana masyarakat menjaga kelestariannya. Nilai kelestarian sebagaimana pula diungkapkan oleh Achmad (2018:179) bahwa bedhaya banyu ning kali wujud tarian untuk syukur lestarinya sumber mata air dengan menghilangkan sifat serakah untuk mengeksploitasinya.

Nilai itulah yang menjadi tambahan dalam mengungkapkan rancangan model laporan water accounting yang berupa laporan dengan kuantifikasi atribut volume, yakni satuan ribuan liter. Laporan tersebut, dengan komponen yang sama dapat ditampilkan atau dikonversi secara kualitatif (penjelasan) moneter. Komponen kualitatif moneter ini dapat disajikan dalam satu laporan dengan kuantifikasi volume. Hal ini sebagaimana ditegaskan oleh Prof. Eko Ganis Sukoharsono bahwa:

Perlu...penambahan uraian dalam GRI 303 water mengungkapkan water accounting 303-3 is water recycled and reused sebagai laporan keberlanjutan, karena dengan penambahan ungkapan tersebut akan mengetahui penggunaan dan yang utama sumber pemeliharaannya. Pemeliharaan sangat tergantung pada budaya penggunaan air. Untuk apa mengetahui sumber tanpa diungkapkan informasi penjelas akan penggunaan dan pemeliharaan.

Lebih lanjut hal senada juga dinyatakan oleh Prof. Adreas Lako sebagai berikut:
Sifat dari laporan water accounting merupakan rincian atau pengungkapan lebih lanjut atas informasi pada laporan keuangan terkait bahan baku dan atau informasi khusus yang terkait dengan air. Jika nantinya laporan tersebut dapat disajikan dalam satuan moneter, maka akan lebih memperjelas pengungkapan informasi alokasi biaya yang digunakan oleh perusahaan dalam hal sumber air dan pelestariannya dalam hal efektivitas dan efisiensi operasional kelestariannya.

Pengungkapan kelestarian sumber mata air menjadi utama di dalam pelaporan air yang digunakan. Hal ini sejalan dengan GRI 303-1 atas water withdrawal by source sebagai pengungkapan atas penggunaan air. Penggunaan air berkaitan dengan Pengendalian diri (Dewi, 2018:89). Pengendalian ini berlaku baik untuk pemenuhan kebutuhan (needs) maupun keinginan (wants). Ajaran tarian bedhaya banyu ning kali mengantur penggunaan air dalam ajaran tuntunan pradikaning banyu (pendidikan pemenuhan air). Pendidikan sebagaimana diungkapkan oleh Ki Sentot Subagyo:

...pradikaning utawa candaning butuhe banyu marang Bedhaya Banyu Ning awujud ngiterin sendang bagong ping sepuluh karep ngilingake larangan nguja hawa nepsu lakune manungsa kanggo menehi butuhe banyu mili kanggo kahanan sendang banyu bagong iki. Iterean mubenge tari simbole ukara panguripan lakune manungsa ning urip ora isa pedhot kanggo manfaate banyu [...terpenuhinya kebutuhan air atas tarian bedhaya banyu ning kali perwujudan mengelilingi sumber mata air bagong dengan sepuluh kali sebagai hasrat hilangnya keinginan berlebih perilaku manusia dalam memenuhi kebutuhan air yang berasal dari sumber mata air bagong ini. Mengelilingi dengan tarian simbol perwujudan perilaku hidup manusia tidak bisa terlepas dari kebutuhan air]. 
Sikap karep (hasrat) kebutuhan air adalah abadi, sebab sebagai dasar hidup. Jika memahami bahwa kareb ini abadi sebagaimana merujuk pada Widyawati, (2012:35) dan Sindhunata (2015:71) bahwa manusia menyadari ketergantungannya pada air, sehingga berupaya untuk tidak terjadi perasaan getun-sumelang keberadaan air. Getun berarti kecewa atau takut terhadap kejadian yang sudah terjadi (kerusakan dan pencemaran air). Sumelang berarti kekhawatiran terhadap sesuatu yang belum terjadi (kebersihan air). Konsep ini juga ditekankan oleh Ki Sentot Subagyo bahwa tarian bedhaya banyu ning kali kanggo awujud sandang kelir ijo lang emas uga nglerem getun sumelang magang cilaka tumrap banyu ing sendang bagong iki [tarian bedhaya banyu ning kali dari wujud baju tari warna hujau dan emas mempunyai makna semangat menjaga kelestarian sehingga menghindarkan dari bencana di sumber mata air bagong].

Kelestarian air menurut Darwin (2018) merupakan wujud menjaga dan memelihara ketersedian dan penggunaan air dari pencemaran. Pencemaran air sebagaimana merujuk pada System of EnvironmentalEconomic Accounting for Water/SEEA-Water (2012) sumber penyebab utamanya berasal dari kegiatan manusia terhadap air. Kegiatan manusia ini menghilangkan kesadaran diri dalam pengelolaan sumber daya air. Mengapa kesadaran diri manusia penting dalam akuntansi manajemen air? Karena akuntansi yang mendasarkan pada Flow accounts dan Asset accounts. Flow accounts meliputi Physical Supply and Use Tables (PSUT), Emission accounts, dan Hybrid and Economic accounts.

PSUT merupakan rerangka utama pada SEEA-Water. Kategori flow pada PSUT adalah dari lingkungan ke ekonomi, dalam lingkup ekonomi, serta dari ekonomi kembali ke lingkungan. Sementara itu, asset accounts mengukur persediaan air di awal dan di akhir periode akuntansi, serta mencatat perubahan yang terjadi selama periode tersebut. Dua macam aset dalam asset accounts terkait air adalah aset produksi (produced asset), sumber daya air (water resources), serta quality accounts. Aset produksi di dalamnya termasuk infrastruktur yang digunakan untuk abstraksi, mobilisasi, dan perlakuan air. Aset sumber daya air merupakan aset yang menggambarkan volume sumber daya air dari berbagai sumber beserta perubahannya yang di sebabkan oleh alam (contoh: hujan, evapotranspirasi, dan lain-lain) maupun aktivitas manusia (contoh: abstraksi).

Kesadaran manusia memberikan nilai utama berjalannya akuntansi manajemen air untuk tetap bersih dan lestari. Nilai ini mempunyai makna fisik dalam tarian bedhaya banyu ning kali dari semua gerakan seluruh tubuh dengan membawa bokor (tempat air) mengelilingi sendang dan sewaktu-waktu dipercikan (meneteskan), tujuannya menyadarkan manfaat yang besar bagi manusia untuk menjaga air bersih (banyu bening) bebas dari bibit penyakit, bebas virus, bisa digunakan untuk membersihkan apa saja demi kelangsungan hidup (Sindhunata, 2015). Kelangsungan hidup mempunyai makna bahwa air merupakan aset yang memberikan jaminan hidup manusia, sehingga harus dijaga keberadaan dan volume ketersediaan air dari pencemaran. Hal ini sebagaimana ditekankan dalam dialog di bawah ini:

Sarah dewi : Pernyataan air sebagai aset... itu bukan wujud eksploitasi namun lebih menekankan pada pemeliharaan...ya...e... e...upaya air untuk tetap terjaga selamanya. Ini aset berharga yang harus disadari.

Whedy : Bagaimana kesadaran seperti ini muncul? Ketika eksploitasi dan pencemaran terus ada tanpa mengindahkan peraturan.

Sarah dewi : Benar...peran diri dalam manusia menjadi peran sentral lebih dari utama, artinya manusia mampu 
mengerti dan memahami bahwa hidup ini membutuhkan air untuk selamanya.

Whedy : Peran diri bagaimana Mbak?

Sarah dewi : Ya...ini tindakan menghindari pencemaran, karena faktor ini menjadi syarat utama air tetap lestari... manusialah yang harus sadar terhadap lingkungan air. Untuk apa ungkapan dan peraturan kalau manusia dalam dirinya tidak pernah menyadari dengan sungguh bahwa air sangat menentukan kualitas hidupnya.

Whedy : Utamakan kesadaran dulu ya...mbak, kalau seperti tindakan ini bagaimana? (sambil menunjukkan foto tarian bedhaya banyu ning kali)

Sarah dewi : Iya...ini yang saya harapkan, kita ini punya cara yang lebih eco (lingkungan) dibanding hanya konsep saja. Kenapa saya sangat setuju sekali...kalau ungkapan itu hanya tulisan yang akan berubah dengan unsur maksud dan tujuan yang dicapai...namun kalau tindakan seperti tarian...apa... tadi...

Whedy : Bedhaya banyu ning kali

Sarah dewi : Iya...ini wujud nyata bagaimana manusia menjaga dan mengakui bahwa air adaah sumber utama yang harus dijaga kelestariannya...hebat ini...sama dengan yang saya temui di daerah kalijambe sragen...ungkapan kecintaan manusia pada air...penting ini bukan kita tidak percaya dengan tulisan namun budaya untuk tindakan...itu penting Mas...eco dan eco itu fisik yang hanya ada di budaya kita...sungguh ini kesadaran untuk nyawang karep. (Nyawang karep senada dalam bahasa Indonesia adalah mengawasi hasrat.)

Whedy : Nyawang karep tarian menjadi perbuatan yang tercatat untuk menjaga pengelolaan penggunaan sumber daya air.

Sarah dewi : Itu...eco...Mas...ini yang menjadi dorongan atas keinginan, harapan untuk terlaksananya pemeliharaan air dari pencemaran dan eksploitasi yang berlebihan. Dan ini merupakan fenomena yang ada saat ini bahwa tulisan tanpa diikuti dengan tindakan atau sikap untuk menjalankan...contoh kita punya sumber namun dieksploitasi tanpa tindakan menjaga air tetap lestari... dilarang membuat sampah disungai...tapi tulisan ada tindakan sampahnya masih disungai muncul...ini tulisan unik tapi masih terpampang...ha...ha...

Whedy :Ecofenomenologi ya....Mbak

Sarah dewi : Iya...maksud keinginan saya seperti itu..cocok bahwa kelestarian dengan tindakan. Ini mampu memberikan tingkatan pada kesadaran...tidak mungkin aktivitas tarian tersebut dilakukan tanpa namanya kesadaran. Membangun jiwa seperti ini tidak cocok di kita hanya dengan peraturan dan tuntutan semata, namun......eksistensi untuk menghindarkan perilaku egoistis untuk menjaga dan 
memelihara serta bertanggungjawab memelihara. Ini menjadi pendekatan simbol tarian sebagai tontonan dan tuntunan menjadi berguna.. .kalau sudah menerima jelas dan pasti akan memelihara karena air itu tidak bisa "protes" hanya memberi. Jadi.......dengan kesadaran nilai memberi menjadi langgeng untuk menyadari kelestarian air sebagai pertanggung jawab diri dengan sumber mata air tersebut. Harmonisasi ini menjadi nilai pengungkapan yang utama dalam mengidentifikasi keberlangsungan air untuk penghidupan masyarakat.

Pengungkapan dialog di atas sejalan juga dengan yang ditegaskan oleh Prof. Eko Ganis Sukoharsono berikut ini:

...GRI 303 water dalam 1 memberikan kesadaran untuk mengungkapkan penggunaan air dan kelestarian untuk menjaga keberlangsungan dengan pengungkapan internal atas sumber air tersebut sebagai water sources significantly pada 303 point 2 .

Pelaporan pengungkapan penggunaan air tersebut menjadi fokus dalam water accounting (Smith, 2010). Mengapa demikian? Karena water accounting menerapkan konsep akuntansi basis akrual dalam mengidentifikasi, mengukur, mencatat, dan melaporkan informasi terkait sumber daya air (Godfrey et. al., 2010). Proses seperti ini menuntut kesadaran penguna air dalam melaporkan penggunaan dan tindakan untuk menjaga keberlangsungan lingkungan sumber mata air, sehingga laporan yang dihasilkan menunjukkan dokumen aktivitas internal yang dilakukan (Handoko, 2014). Aktivitas internal menjaga kelestarian menurut Pambagio (2015) dan Remali (2016) menunjukkan tindakan menurut penglihatan sehingga pasti tepat dan benar. Hal ini senada dengan ilustrasi menarik yang dijelaskan Achmad (2014:63) bahwa misalnya kita menari dan saya melihat sendang air di depan pasti saya tidak akan merusaknya. Jadi melihat itu akan melahirkan tindakan yang benar dan tepat. Pada langkah ini, kita sendiri yang menentukan kelestarian terjaganya sumber air untuk hidup. Jika kita sudah bertindak membangun kesadaran seperti ini kerusakan pasti terhindar. Ungkapan yang mendukung dengan penjelasan Prof. Andreas Lako bahwa:

Oleh...budaya yang diyakini bersama...kita mampu mengungkapkan tindakan kelestarian air yang berdasar atas penglihatan dan pengertian keadaan yang ada sekarang, esok dan seterusnya. Karena...manusia mempunyai sifat perusak untuk mencapai keinginannya yang terus bertambah. Olehnya tuntutan peraturan tidak bernilai kalau kesadaran tidak tumbuh dahulu. Membangun kesadaran yang dinyakini bersama dengan nama budaya tarian menjadi modal berharga untuk kesesuai ungkapan pelaporan dengan nyata dan kelestariannya. Apresiasi saya untuk budaya seperti ini dalam membangun kesadaran penggunaan air, dengan tindakan lokal untuk internasional.

Pedoman tersebut memberikan tambahan dalam sustainability report (laporan keberlanjutan) pada GRI 300 tentang Environmental Impacts khususnya pelaporan GRI 303-3 atas keberlanjutan penggunaan air. Hal ini sebagaimana sejalan dengan yang diungkapkan oleh Ki Sentot Subagyo, berikut ini

Whedy

: Ki...tarian bedhaya banyu ning kali punika dipun rewes uga sendang bagong kanggo menapa? (Bapak...tarian bedhaya banyu ning kali yang dilaksanakan di sedang bagong seperti ini digunakan untuk apa?]

KiSentot S : Kawontenan kahana antawisipun dathengipun syukur 
acukupi banyu lan kahana salebeting lestarine sendang bagong nyumberake banyu. [Wujud nyata untuk mensyukuri terpenuhinya air dan perasaan untuk menjaga lestarinya sumber air sendang bagong.]

Whedy : Ungkapan kahana kados pripun Ki...uga sanget ngungkapake rasa rahayu syukur menika? [Pernyataan yang seperti apa Bapak..........yang bisa mengungkapkan perasaan bersyukur seperti itu?]

Ki SentotS : Bedhaya banyu ning kali awujud tuntunan lan tontonan tarian ungkapan slametan lan prastasti laku ne kahana jati urip jaga lestarine banyu sumerep punapa ingkang yektos lumampah jaga jatosipun langgeng. [Bedhaya banyu ning kali merupakan petunjuk dan hiburan berupa tasyakuran dan keyakinan kuat perjalanan sejati hidup untuk menjaga lestarinya air dalam membuat terjaganya untuk seterusnya.]

Whedy : Langgeng toyonipun napa lestarinipun sendang bagong $K i$ ?[Terjaga seterusnya air atau lestarinya sumber mata air bagong Ki?]

Ki Sentot S : Yo..kuwi nempel raket marang lelaku tarian awujud saksi bekti jaga lestarinipun sendang ingkang minturapi lestarine banyu ingkang sumber gawe lakune urip ing warga desa wonorejo. [iya... itu melekat kuat dalam tarian sebagai perwujudan lestarinya air untuk sumber air yang digunakan dalam hidup masyarakat desa wonorejo.]

Whedy : Tumrapipun ater-ater kawontenan kagem lestarinipun sen- dang bagong gih Ki. [Penjelasan yang dimaksud perwujudan bagi lestarinya sumber mata air bagong gih?]

Ki SentotS : Leres sanget uga wujudipun jagi lestarinipun sendang miturapi lir slametan lelakuning tarian bedhaya banyu ning kali ingkang simbolake baktine karo toyo kangge langgengipun urip. [Benar sekali sebagai perwujudan menjaga lestarinya sumber air diwujudkan dalam tasyakuran pertunjukkan tarian bedhaya banyu ning kali sebagai simbol perwujudan pentingnya air untuk terjaganya hidup.]

Perwujudan kesadaran menjaga sumber air melalui tarian bedhaya banyu ning kali merupakan perilaku internal masyarakat desa Wonorejo. Perilaku ini memberikan pedoman menjaga lestarinya sumber mata air melalui tindakan bersama. Tindakan bersama (joint action) menjadi sumber pelaporan yang disepakati berdasarkan terjaganya keadaan sumber air yang ada sekarang, di sini tentu berhasil tepat dan benar dalam melaporkan kondisi pengaruh lingkungan terhadap keberadaan sumber perolehan air (Darwin, 2018).

Kondisi seperti itu sejalan dengan yang dinyatakan Ki Sentot Subagyo bahwa lelaku guyub bedhaya banyu ning kali awujud ngawasi karep supados salira lan ngrahayuni sedang kange mung urip...ojo mung ngujo serakah ngrusak pepandang sing wis ono...lestarine urip ketok (Aktivitas bersama bedhaya banyu ning kali perwujudan mengawasi keinginan supaya menjaga dan merawat sumber mata air untuk satu tujuan yaitu hidup...jangan hanya ingin serakah merusak lingkungan yang sudah terjaga...berlangsungnya hidup terjamin. Keyakinan diri seperti ini membuat segala tindakan didasarkan kepada kelestarian sumber perolehan air yang telah 
ada (Pambagio, 2015; Patrick, 2016). Mengapa demikian? Karena keinginan memberikan respon pada keinginan pribadi untuk membangun kesadaran dalam

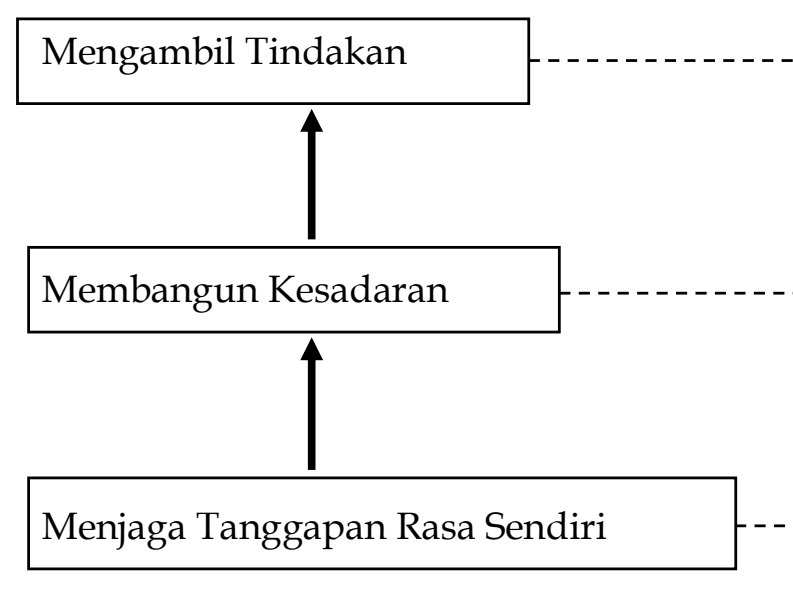

mengambil tindakan sebagai pelaporan pribadi yang benar. Konsep ini dapat dijelaskan dalam gambar berikut ini:

Bertindak menurut penglihatan diri dengan benar dan tepat terhadap keadaan yang ada sekarang, dan selamanya, tanpa catatan serakah

Membangun keadaan yang melibatkan diri dan orang lain menemukan rasa sama dengan sumber mata air bukan dalam komoditas

Menemukan kebahagian bersama sumber mata air

\section{Gambar 3 \\ Pelaporan Pribadi Terhadap Air}

Ketiga langkah tersebut menjadikan pedoman dalam merumuskan kembali tambahan dalam pengungkapan keberlanjutan atas GRI 300 Environmental Impacts dalam GRI 303 Water pada 303-3 Water recycled and reused. Tambahan ini memberikan tanggung jawab sesungguhnya diri manusia (pangawikan pribadi) tentang pentingnya air. Perwujudan seperti ini membuat ketergantungan manusia dengan air sehingga merasa satu memiliki, tentrem, damai dan bahagia.

Kelestarian terjaganya sumber perolehan air dengan manusia sebagaimana pula diungkapkan oleh Handoko (2014), Pambagio (2015), Remali (2016), dan Febiola (2018). Mereka mengungkapkan bahwa penerapan pengungkapan atau pelaporan atas air melalui laporan tahunan, laporan keberlanjutan, water accounting report, atau bentuk dan media pelaporan lain mendasarkan pada dua aspek yang saling berkaitan, yakni lingkungan dan manusia. Kedua aspek ini menjadi prioritas utama dalam pelaporan GRI 303-3.

Pengetahuan mengenai diri dan lingkungan menghasilkan refleksi dalam menjaga keutuhan diri manusia dengan lingkungan.
Refleksi yang diwujudkan dalam tarian bedhaya banyu ning kali untuk menghasilkan makna kehidupan menjaga sumber mata air (Achmad, 2014:89; 2018:179). Ketika individu dan masyarakat mencapai tataran kebijaksanaan, memiliki rasa memiliki, berjiwa besar, berguna bagi diri dan sesamanya menjadi kehidupan yang tata, titi lan tentrem menuju lingkungan sumber mata air yang lestari. Refleksi diri ini merupakan bagian penting dari transformasi kesadaran jiwa dari juru catat (pencatatan) penggunaan air menuju kelestarian yang paling hakiki.

Tarian bedhaya banyu ning kali memberikan eksistensi kehidupan yang tidak terpisahkan antara manusia dan air. Kesatuan sebagai simbol pengelolaan sumber mata air untuk mempertahankan kelestarian dan keselarasan menuju lingkungan yang tetap harmonis. Perwujudan seperti ini menunjukkan eksistensi ganda dalam kehidupan sebagai arena interaksi secara emosional.

Mengapa demikian? Eksistensi ini perwujudan diri yang dituntun oleh hasil olah rasa makna tarian bedhaya banyu ning kali yang "membiasakan" diri mencapai tataran kebijaksanaan, berjiwa untuk menjaga bagi 
diri dan sesamanya, dimana hal ini menjadi ciri pribadi sehat, bahagia (begja) dan sejahtera (Endraswara, 2010:43; Sindhunata, 2015:66). Refleksi diri merupakan bagian penting dari kesadaran jiwa dari juru catat hingga menjadi manusia mawas diri. Pencapaian ini menghilangkan ketidak jujuran dan kesewenang-wenangan.

Suasana tatanan pengelolaan tersebut menitikberatkan pada dua nilai utama, yaitu pertanggungjawaban dan kerukunan. Ruang publik terbangun dalam sebuah tatanan masyarakat yang terjaga sedemikian rupa, sehingga keteraturan dan keselarasan dipertahankan. Bentuk-bentuk konflik keserakahan, ambisi pribadi, ketidakpekaan, emosi berlebihan, dan keunggulan diri sendiri dihindari. Tatanan seperti ini merujuk pada penjelasan Sarah dewi sebagai berikut:

Pola tindakan yang menyakini hiburan tarian bukanlah pertanggung jawaban sesaat, namun...turun temurun yang menyelaraskan ungkapan syukur dan menjaga. Sungguh... tatanan ini menjadikan nilai tresna dalam reaksi emosional yang dapat dipertahankan...bukan sumber mata airnya...yang utama yaitu penggunanya. Karena apapun yang dipertunjukkan secara terbuka tersebut...maksud saya tarian merupakan bentuk reaksi publik dan pribadi. Ini uraian pertanggungjawab yang masuk dalam kepercayaan...kekal dan terjaga dari pada hanya catatan pelaporan yang belum tentu terjaga dan kekal...benar kan?

Penjelasan di atas sejalan dengan Ki Sentot Subagyo yaitu:

Mung banyu kuwi sifatte meneng, sing gawe bubrah ya...lelaku manungsa. Lelaku iku lah sing diwujude karo tontanan tari bedhaya banyu ning kali ngitari sendang. Mung ngitari ketokane nanging khasil sing diwujude karo ngelestareake dina iki lan sakputune... kuwi sing iso dimaknai urip mung mliri saka kahana jaga sendang bagong [Air itu sifatnya hanya diam, yang membuat rusak ya...perilaku manusia. Perilaku sebagaimana diwujudkan dalam hiburan tari bedhaya banyu ning kali mengelilingi sumber mata air. Hanya mengelilingi yang terlihat namun hasil yang diwujudkan dengan melestarikan hari ini sampai seterusnya...hal ini arti hidup menjaga sumber mata air bagong.]

\section{SIMPULAN}

Wujud keharmonisan hidup menjadikan budaya tarian bedhaya banyu ning kali mengungkapkan perlakuan air. Aktivitas di dalam pertanggungjawaban membangun kesadaran water accounting yang dinyakini bersama. Kegiatan ini ditujukan untuk memelihara tatanan dan mencegah datangnya kehancuran sumber mata air. Jadi, bagaimanapun bahwa manusia memegang peran aktif dalam memelihara tatanan ini dan mampu mempengaruhi keberadaan sumber air. Hubungan sosial yang tertata baik menjadi sebuah sarana menuju dan sebuah kondisi untuk meningkatkan keadaan terpeliharanya lingkungan penghasil air, yaitu sumber mata air Bagong.

Kesadaran tersebut menjadi modal berharga untuk kesesuaian ungkapan pelaporan secara nyata dan kelestariannya. Pelaporan yang memfokuskan bagaimana penggunaan dan aktivitas intenal dalam menggunakan air. Aktivitas diri manusia dalam menyajikan laporan keberlanjutan air. Laporan kesadaran yang berisikan tanggung jawab perilaku manusia. Tanggung jawab yang difokuskan untuk menjaga dan melestarikan, pedoman ini memberikan tambahan dalam sustainability report (laporan keberlanjutan) pada GRI 300 tentang Environmental Impacts khususnya pelaporan GRI 303-3 atas keberlanjutan penggunaan air.

\section{DAFTAR PUSTAKA}

Achmad, S.W. 2014. Ensklopedia Kearifan Jawa, Menggali Kearifan Jawa Berdasarkan 
Karya Agung Para Pujangga. Cetakan Pertama. Penerbit Araska. Yogyakarta.

Achmad, S.W. 2018. Etika Jawa Pedoman Luhur dan Prinsip Hidup Orang Jawa. Cetakan I. Penerbit Araska. Yogyakarta. Arya, A., dan Mittendorf, B. 2011. Supply Chains and Segment Profitability: How Input Pricing Creates a Latent CrossSegment Subsidy. The Accounting Review. 86 No 3: 805-824.

Dahana, R.P. 2015. Ekonomi Cukup-Kritik Budaya pada Kapitalisme. Penerbit Buku Kompas. Jakarta.

Darwin, A. 2018. Sustainability Reporting Practice in Indonesia. Working Paper (PPt). Disajikan dalam Workshop in House Training CSRS. Universitas Jember. 13 Oktober.

Endraswara, S. 2010. Etika Hidup Orang Jawa: Pedoman Beretika dalam Menjalani Kehidupan Sehari-hari. Cetakan Pertama. Penerbit Narasi. Yogyakarta.

Febiola, A. 2018. Water accounting Pada Perusahaan Air Minum Dalam Kemasan: Perlukah Diterapkan Di Indonesia?. Skripsi. Jurusan Akuntansi Fakultas Ekonomi dan Bisnis Universitas Jember.

Godfrey, J., A. Hodgson, A. Tarca, J. Hamilton, and S. Holmes. 2010. Accounting Theory. $7^{\text {th }}$ ed. John Wiley \& Sons Australia, Ltd. Queensland.

Handoko, Y. 2014. Implementasi Social and Environmental Diclosure dalam Perspektif Teoritis. Jurnal JIBEKA. 8(2): 74.

Lako, A. 2018. Akuntansi Hijau: Isu, Teori dan Aplikasi. Penerbit Salemba Empat. Jakarta.

Mulder, N. 2011. Mistisisme Jawa: Ideologi di Indonesia. Cetakan V. Penerbit LKiS. Yogyakarta.

Molden, D. 2007. Accounting for water use and productivity. SWIM Paper. 1: 1-15.

Nasir, A., E. I. Ilham, dan V. I. Utara. 2014. Pengaruh Karakteristik Perusahaan dan Corporate Governance Terhadap Pengungkapan Sustainability Report
Pada Perusahaan LQ45 yang Terdaftar. Jurnal Ekonomi 22(1): 1-18.

NCSR (National Center For Sustainability Reporting). 2018. GRI Standards Certified Training on Sustainability Reporting.

Pambagio, Agus. 2015. Nasib Pengelolaan Air di Indonesia Pasca Pembatalan UU Sumber Daya Air. https://news.detik.com/ kolom/2917278/nasibpengelolaan-airdi-Indonesia-Pasca-Pembatalan-UUSumber-Daya-Air [Diakses pada 09 Januari 2019].

Patrick. 2016. Akibat dari Penguasaan Air Tanah yang Berlebihan. https://www. tanindo.net/akibat-dari-pengunaan-airtanah-yang berlebihan. [Diakses pada 11 Januari 2019].

Remali, A. R. M., N. M. Husin, I. M. Ali, and B. Alrazi. 2016. An Exploratory Study on Water Reporting Among Top Malaysian Public Listed Companies. Procedia Economics and Finance 35: 64-73.

Sabdacarakatama, K. 2011. Serat Wedhatama. Cetakan pertama. Penerbit Narasi. Yogyakarta

Sindhunata. 2015. Budaya dan Religi Jawa dalam Hidup. Penerbit Omah Petroek. Yogyakarta.

Smith, D.B. 2010. Is There an Ecological Unconscious? New York Times, 31 Januari.

Schulte, P. 2014. Defining Water Scarcity, Water Stress, and Water Risk: It's Not Just Semantics. http://pacinst.org/ water-definitions/. [Diakses pada 09 Januari 2019].

Water Accounting Standards Board (WASB). 2014. Water Accounting Conceptual Framework for the Preparation of General Purpose Water Accounting Reports. Canberra. Commonwealth of Australia.

Widyawati, I. 2012. Etika Jawa: Menggali Kebijaksanaan dan Keutamaan demi Ketentraman Hidup Lahir Batin. Penerbit Shaida. Yogyakarta. 